\title{
Isolates of Lipolytic, Proteolytic and Cellulolytic Bacteria from Palm Oil Mill Effluent and Their Potency as Consortium
}

\author{
Muhammad Said ${ }^{\#}$, Muhammad Faizal ${ }^{\#}$, Bambang Yudono ${ }^{*}$, Hasanudin$^{*}$, Sriwi Pertiwi Estuningsih ${ }^{+}$ \\ ${ }^{*}$ Chemical Engineering Department, Faculty of Engineering, Universitas Sriwijaya, Palembang, 30139, Indonesia \\ E-mail: saidm_19@yahoo.com
}

${ }^{*}$ Chemistry Department, Faculty of Mathematics and Natural Science, Sriwijaya University, Palembang, 30139, Indonesia

${ }^{+}$Biology Department, Faculty of Mthe athematics and Natural Science, Sriwijaya University, Palembang, 30139, Indonesia

\begin{abstract}
Study of lipolytic, proteolytic and cellulolytic bacteria in variety, especially the study of isolation technique to identify, cultivation technique to produce many researchers have done enzyme and activity test. While the study on lipolytic, proteolytic and cellulolytic that support the consortium bacteria having the capability of degrading fats, protein and cellulose being the wastewater components have not been conducted yet. This is a novelty of this study. This study aims to obtain consortium of bacteria having lipolytic, proteolytic and cellulolytic capability from the palm oil mill effluent. The lipolytic, proteolytic and cellulolytic bacteria were isolated from the wastewater using medium mineral (MM), and each of the bacteria was enriched by vegetable oil, casein and Carboxy Methyl Cellulose (CMC). Each of the isolates of bacteria that had been selected was conducted oxygen requirement and synergism tests, and then the consortium of bacteria was wade. Two types of consortium of the bacteria were obtained, that is a facultative anaerobic consortium that consists of two bacteria Bacillus toyonensis strain BCT - 7112 and Stenotrophomonas rhizophila strain e-p10, and the aerobic consortium that consists of three bacteria, namely: Bacillus cereus ATCC 14579, Pseudomonas azotoformans strain NBRC 12693 and Burkholderia cepacia ATCC 25416.
\end{abstract}

Keywords - bacteria; lipolytic; proteolytic; cellulolytic; consortium.

\section{INTRODUCTION}

Study concerning with lipolytic, proteolytic and cellulolytic bacteria had been conducted. The study was conducted in variety, especially the study of isolation technique to identify, cultivation technique to produce enzyme and activity test. The characteristic study of lipolytic, proteolytic and cellulolytic that support the consortium bacteria having the capability of degrading fats, protein, and cellulose being the wastewater components have not been conducted, so the study was a new thing to make the consortium of bacteria becoming potential to treat the organic waste containing fat residue, protein, and cellulose. The study of lipolytic bacteria was conducted starting form isolation, characterization identification, and lipolytic activity test. Ali et.al.[1] isolated the bacteria for degradation of fats from the oily contaminated soil obtained nine genera, namely Pseudomonas, Bacillus, Aeromonas, Staphylococcus, Streptococcus, Enterococcus, Serratia, Yersinia, dan Lactobacillus. Arpigny and Jaeger [2] conducted the characterization and classification of the enzyme from the lipolytic bacteria Pseudomonas and group of gram-positive bacteria.

Bestari and Suharjono [3] carried out the activity test of an enzyme of lipase and identified the lipolytic bacteria from wastewater of fish treatment industry and found bacteria of Staphylococcus aureus B3 that possessed the enzyme activity of lipase 4,05 of $4.05 / \mathrm{ml}$ for 34 hours of incubation time. Gludice et al. [4] conducted isolation of lipolytic bacteria and the activity test from Antartic sea. They found three genera of bacteria, namely: Pseudoalteromonas, Psychrobacter, and Vibrio. Lipolytic activity was tolerant of $\mathrm{NaCl}$ (1-11\%) and low temperature $\left(4-15{ }^{\circ} \mathrm{C}\right)$. Lee et al. [5] found genus of that showed proteolytic and lipolytic activity. The bacteria were isolated from the contaminated soil in the market area. Lodha et al. [6] found fungi of Rhizopus nigricans having lipolytic property and produced biosurfactant indicated from bioemulsification activity test. Mandeputi et al. [7] conducted fermentation of vegetable oils using lipase enzyme resulted by four isolates of bacteria from the soil sample. The vegetable oil used included coconut oil, bean oil mustard oil, olive oil, sunflower oil and 
soybean oil that had various types of the fatty acid ester. The results showed conformity among the lipase enzyme of each bacteria with lipase activity for each vegetable oil.

Odeyemi et al. [8] found isolate of Pseudomonas from restaurant having the capability to produce three enzymes, that is lipase, protease, and amylase. Activity of each enzyme is lipase $0.073 \mathrm{mM} / \mathrm{min} / \mathrm{ml}$, protease 50 $117 \mathrm{mM} / \mathrm{min} / \mathrm{ml}$ and amylase $7.7-117 \mathrm{mM} / \mathrm{min} / \mathrm{ml}$ after 12 hour incubation. Pallavi [9] succeeded to produce lipase from an isolate of Bacillus subtilis P-1V1 from the oilcontaminated soil. The highest concentration of lipase found at 48 hours was $8.8 \mathrm{u} / \mathrm{ml}$. Phong [10] succeeded to isolate Acinetobacter soli strain AL3 from wastewater of the food industry and restaurant being capable of degrading lipids. Assessment of proteolytic bacteria that had been conducted by Donkor et al. [11] obtained for genera of bacteria, namely: Lactobacillus, Bifidobacterium, Lactobacillus and Streptococcus that had proteolytic activity being bacteria of lactic acid and probiotic bacteria from fermented milk. Rodarte et al. [12] examined protease activity of bacteria, namely: Bacillus megaterium, B. subtilis, Enterobacter agglomerans, Kurthia sp, Pseudomonas paucimobilis and Tatumella ptyseos isolated from the coffee bean (Coffea arabica L.). The maximum activity average of protease enzyme resulted in $\mathrm{pH}$ 9. Megha, S.V., and B. Annadurai [13] found seven isolates of bacteria from fresh milk and after identification, namely: Staphylococcus aureus, Bacillus cereus, Pseudomonas aeruginosa, Proteus mirabilis, Escherichia coli, Micrococcus luteus and Serratia marcescens and five of them had proteolytic activity, namely: Bacillus cereus, Pseudomonas aeruginosa, Proteus mirabilis, Micrococcus luteus and Serratia marcescens.

Assessment of proteolytic bacterial had been conducted by previous researchers starting from isolation to the examination of protease enzyme activity. The following researchers had isolated proteolytic bacteria from various sources. Donkor et al. [11] conducted the lipolytic test from lactic acid bacteria and probiotic bacteria resulting from fermented milk and found for general bacteria, that is Lactobacillus, Bifidobacterium, Lactobacillus, and Streptococcus possessing proteolytic activity.

Rodarte et al. [12] examined activity of protease from bacteria of Bacillus megaterium, B. subtilis, Enterobacter agglomerans, Kurthia sp, Pseudomonas paucimobilis and Tatumella ptyseos isolated from the coffee bean (Coffea arabica L.). The average of maximum activity of protease enzyme was obtained at $\mathrm{pH}$ 9. Megha, S.V., and B. Annadurai [13] found seven bacteria isolates from fresh milk and after identification, they were Staphylococcus aureus, Bacillus cereus, Pseudomonas aeruginosa, Proteus mirabilis, Escherichia coli, Micrococcus luteus and Serratia marcescens and five of them having proteolytic activity, that is: Bacillus cereus, Pseudomonas aeruginosa, Proteus mirabilis, Micrococcus luteus and Serratia marcescens. Rupali [14] succeeded in isolating Bacillus sp from soil that had proteolytic characteristics. The maximum activity of protease was $0,0233 \mathrm{U} / \mathrm{ml} /$ achieved at $\mathrm{pH} 7,4$ and temperature of $60{ }^{\circ} \mathrm{C}$. Rodarte et al. [12] found $52.5 \%$ of bacteria isolated from coffee bean with proteolytic characteristics at $\mathrm{pH} 9$, but only three of the bacteria isolates possessing the highest proteolytic activity, namely: Bacillus subtilis 333 (27.1 U), Tatumella ptyseos (27.0 U) and B. megaterium 817 (26.2 U). Three bacteria that is: Bacillus subtilis, Bacillus thuringiensis, and Lysinibacillus fusiformis were obtained from wastewater of chicken farms having characteristics of lipolytic-proteolytic and producing biosurfactant.

Study of cellulolytic bacteria carried out by the previous researchers concerned with isolation and examination of the activity of cellulase enzyme. Balamurugan, et al. [15] found five isolates of bacteria having cellulolytic characteristics with maximum cellulosic activity at $\mathrm{pH} 7$ and a temperature range of $30-40{ }^{\circ} \mathrm{C}$. The five isolated bacteria were obtained from soil of tea gardens. Dubey et .al. [16] isolated Bacillus subtilis having cellulolytic characteristics from biogas mud. The maximum cellulolytic activity was found at a salt concentration of $1 \%, \mathrm{pH} 7$ and incubation temperature of 35 ${ }^{\circ} \mathrm{C}$. Hatami et al. [17] isolated cellulolytic bacteria from soil forest and soil of farming and found bacteria with coccus and small bar form. The average index of bacteria from the forest soil was found 1.60 smaller than the cellulolytic index of the agricultural soil 2.10. Huang et. Al. [18] found 17 genera of bacteria from larva digestion channel of Holotrichia parallela with cellulolytic characteristics. The genera of bacteria are Pseudomonas, Ochrobactrum, Rhizobium, Cellulosimicrobium, Microbacterium, Bacillus, Dyadobacter, Siphonobacter, Paracoccus, Kaistia, Devosia, Labrys, Ensifer, Variovorax, Shinella, Citrobacter, and Stenotrophomonas. Irfan et al. [19] succeeded in isolating Cellulomonas sp. ASN2 with the cellulolytic property of the soil. The optimum condition for the activity of cellulose enzyme was achieved at $\mathrm{pH} 7.5$ and incubation temperature of $60{ }^{\circ} \mathrm{C}$. Wenzel et al. [20] obtained two order bacteria of digestion channel of insect of Zootermopsis angusticollis, that is: actinomycetes consisting of three genera, namely: Cellulomonas / Oerskovia, Microbacterium and Kocuria and Bacillales consisting of three genera, namely: Bacillus, Brevibacillus and Paenibacillus. Each of the genera had cellulolytic characteristics in aerobic condition, as well as, facultative anaerobic. This research aims to obtain consortium of bacteria having lipolytic, proteolytic and cellulolytic capability from the palm oil mill effluent.

\section{MATERIAL AND METHOD}

\section{A. The sampling of Wastewater from Palm Oil Mill as} Bacteria Isolate Source

Wastewater was taken from two parts, that is: bottom part (substrate/sediment) as a source of anaerobic bacteria isolate and surface part as a source of aerobic bacteria isolated. The sample for each part was taken using a random sampling method by determining three sample stations (cooling pond 1 , anaerobic pond and cooling pond 2). The sediment was taken $1-2 \mathrm{~kg}$ and a sample of the surface part $1-2$ liter at each station aseptically and all of the samples were stored in coolbox and taken to the microbiology laboratory for bacterial isolation.

\section{B. Isolation of Bacteria from Samples of Wastewater from Palm Oil Mill and Oxygen Requirement}

Sample of sediment was taken $5 \mathrm{~g}$ and that of surface part $5 \mathrm{ml}$ was inoculated in $45 \mathrm{ml}$ mineral medium in Erlenmeyer with a volume of $250 \mathrm{ml}$. Culture was incubated at room 
temperature for $2 \times 24$ hours and then it was diluted starting from $10^{-1}$ to $10^{-6}$, and each dilution was cultured at medium Plate Count Agar (PCA) in Petri disk. The culture in Petri disk was inoculated for $2 \times 24$ hours at room temperature. Each colony was purified to obtain pure indigenous bacteria isolate. Each of the pure isolates was tested for oxygen requirement by inoculating one ose to the medium of Nutrient broth (NB) and incubated at a temperature of $37{ }^{\circ} \mathrm{C}$ for $2 \times 24$ hours. The growth of each bacteria isolate at the NB medium was observed cell distribution vertically. If the increase was concentrated at the surface of NB medium, it indicated the aerobic characteristics, but if the growth distributed vertically from subsurface to bottom of NB medium, it indicated the facultative anaerobe.

\section{Selection of Lipolytic Bacteria Isolate}

Each of indigenous bacteria isolates selected having the potency to degrade oil/fat. The selection was carried out by using the mineral medium (MM) with composition per liter, that is $\mathrm{MgSO}_{4} .7 \mathrm{H}_{2} \mathrm{O}$ of $0.02 \mathrm{~g}$; $\mathrm{KNO}_{3}$ of $0.075 \mathrm{~g} ; \mathrm{K}_{2} \mathrm{HPO}_{4}$ of $0.05 \mathrm{~g} ; \mathrm{FeSO}_{4} \cdot 7 \mathrm{H}_{2} \mathrm{O}$ of $0,002 \mathrm{~g} ; \mathrm{CaCl}_{2} \cdot 2 \mathrm{H}_{2} \mathrm{O}$ of $0,004 \mathrm{~g}$ and bacto agar of $15 \mathrm{~g}$ (Atlas, 2010). The medium was added with vegetable oil of $1 \mathrm{ml}$ and $\mathrm{pH}$ indicator Bromo-Thimol Blue (BTB) of 0,002 g/l. Each of the isolates was made into suspension in sterilized aquadest, disc paper with a diameter of $6 \mathrm{~mm}$ was immersed into the bacteria isolate suspension that would be examined, and it was inoculated in the surface of MM agar having been added by vegetable oil and BTB. The culture was incubated for a temperature of $37{ }^{\circ} \mathrm{C}$ for $2 \mathrm{x}$ 24 hours. Colour changed from blue to yellow showed the bacteria isolate examined was lipolytic.

\section{Selection of Indigenous Bacteria Isolate having the capability of degrading Cellulose (cellulitis)}

Each of indigenous bacteria isolate was selected cellulolytic characteristics. The selection was conducted by using MM Agar plate having been added with Carboxy Methyl Cellulose (CMC) of $0.1 \%$. Each of isolate was made a suspension in sterilized aquadest, disc paper with diameter of $6 \mathrm{~mm}$ was immersed into the bacteria isolate suspension being examined and inoculated in the surface of MM Agar having been added with CMC. The culture was incubated at $37{ }^{\circ} \mathrm{C}$ for $2 \times 24$ hours. Clear zone appeared around the disc paper if the growth bacteria was able to degrade cellulose.

\section{E. Selection of Indigenous Bacteria Isolate having the} capability of degrading Protein (proteolytic)

Each of indigenous bacteria isolates selected for proteolytic characteristics. Selection was conducted using MM Agar added with casein of $1 \mathrm{~g} / \mathrm{l}$. Each of isolate was made a suspension in sterilized request. Paper disk with a diameter of $6 \mathrm{~mm}$ was immersed into the suspension of the bacteria isolate that would be examined and inoculated into the surface of MM Agar that has been added with casein. Clear zone formed around the disc paper if the growth bacteria in the medium was able to degrade casein.

\section{F. Synergism test among the bacteria isolates}

Eleven of bacteria isolates was carried out synergism test. Each of bacteria isolate was made inoculum by taking the bacterial culture using ose needle and then it was inserted into the liquid medium (Nutrient broth), and it was incubated at a temperature of $37^{\circ} \mathrm{C}$ for 24 hours. Solid medium (Nutrient agar) was prepared to examine the bacteria isolate in Petri disk by applying spread plate method of $0.1 \mathrm{ml}$ inoculum of bacteria isolate 1 using drygal sky at the surface media of NA, while other bacteria isolate inoculum (isolate of bacteria 2 - 11) was placed at the surface of agar using disc paper having been immersed in the inoculum. Each of the isolate was conducted similarly to bacteria isolate one so that the bacteria characteristics of synergism and antagonism could be known and then it was incubated, and the growth of each isolate was observed. Isolate of bacteria having the potency of synergism was indicated by not forming resistant zone being a clear area around the disc paper.

\section{G. Bacteria Identification}

Each bacterial isolate was extracted using a bacterial DNA extraction kit (Promega). The obtained DNA was stored at $4^{\circ} \mathrm{C}$ overnight to dissolve completely in TE $1 \mathrm{x}$ buffer and then stored at $-20^{\circ} \mathrm{C}$ for long-term storage. The purity and concentration of DNA are done quantitatively and qualitatively. The quantitative calculation was determined by spectrophotometer at $260 \mathrm{~nm}$ and $280 \mathrm{~nm}$ wavelength, then calculated the absorbance ratio. DNA quality test was done by electrophoresis method using agarose gel with concentration $0.8 \%$. DNA quality is good when the DNA bands look clear, thick, there is only one band and no shadow under the band (smear) and compared with the marker (DNA marker). The obtained 16S-rRNA gene was amplified using a Polymerase Chain Reaction (PCR) device. The primer used in amplification consists of forwarding Bact 27F: 5'- AGA GTT TGA TCA TGG CTC AG -3 ') and reverse primary (Union 1492R: 5'-GGT TAC CTT GTT ACG ACT T-3'). The stages of PCR conditions used for amplification were predenaturation $\left(95^{\circ} \mathrm{C} 3\right.$ minutes one time), denaturation $\left(95^{\circ} \mathrm{C} 0.5\right.$ minutes 30 times $)$, annealing $\left(55^{\circ} \mathrm{C} 1\right.$ minute), elongation $\left(72{ }^{\circ} \mathrm{C} 1.5\right.$ minutes $)$, postElongation $\left(72{ }^{\circ} \mathrm{C} 5\right.$ minutes one time).

The amplified DNA, separated with $1 \%$ agarose gel electrophoresis, was further visualized using ethidium bromide dye and detected by UV light on UVtransilluminators. The detection results were documented. Analysis of DNA sequencing data encoded 16S rRNA BLAST NCBI. Determination of pure DNA sequence (sequencing) was done by sending DNA of purification result of MACROGEN; then sequencing result was analyzed with Bioedit software and data which had been processed was matched with data at gene bank http://blast.ncbi.nlm.nih.gov/ which would show the genetic kinship of the species (Phylogenetic Tree).

\section{RESULTS AND DISCUSSION}

\section{A. Isolation and Selection of cellulolytic, proteolytic, and lipolytic bacteria}

Eleven bacteria were obtained from three ponds of the wastewater treatment system of palm oil mill in which five bacterial isolates were obtained from cooling-1 pond, and three bacterial isolates were obtained in the anaerobic pond, as well as, in the cooling- 2 pond. Oxygen requirement test showed that there were five isolates of facultative anaerobic 
bacteria and six isolates of aerobic bacteria. Selection of the ability to degrade cellulose, protein, and fat was conducted to all bacterial isolates either aerobic or facultative anaerobes. The medium contained cellulose substrate for ability test to degrade cellulose (cellulolytic) if the bacteria grown in the medium was able to degrade cellulose, clear zone formed due to the conversion of insoluble cellulose in the medium into simple sugar substance such as glucose being highly dissolved in the medium. Dissolve glucose changed medium become clear. The ability test to degrade protein was conducted in medium containing milk protein (casein). Bacteria have the capability to degrade casein (less dissolved so that the medium being white) to produce amino acids that dissolved in the medium, so that clear zone was formed.

The medium containing vegetable oil was used for degrading fat (lipolytic), and glycerol and fatty acid was produced if the grown bacteria degraded the fat in the medium. Fatty acid produced would reduce medium $\mathrm{pH}$ to be more acid and change color of $\mathrm{pH}$ indicator of Bromothymol Blue from blue to yellow. Results of degradation tests of cellulose, milk protein and vegetable oil with bacterial isolates either aerobic or facultative anaerobes are shown in Figure 1.

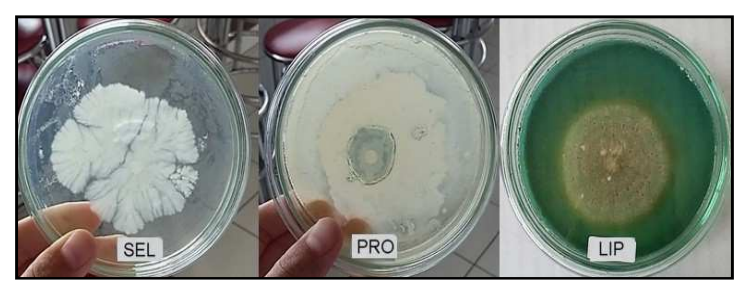

Fig. 1 Test results of cellulolytic (SEL), proteolytic (PRO) and lipolytic (LIP) of bacterial isolates

The bacteria selected with characteristics of anaerobic, cellulolytic, proteolytic, and lipolytic was tested its capability to produce gas The bacteria were able to produce gas in medium, and the produced gas was stored in Durham tube while the bacteria did not produced gas, no gas was stored in Durham tube. Gas was produced as methane $\left(\mathrm{CH}_{4}\right)$ in an anaerobic condition, and it was produced as carbon dioxide $\left(\mathrm{CO}_{2}\right)$ in aerobic condition. Results of selection to characteristics or ability of bacteria to degrade the wastewater component of palm oil mill are shown in Table 1 .

TABLE I

SELECTION RESULTS OF CHARACTERISTICS AND ABILITY OF BACTERIA

REQUiRED IN WASTEWATER TREATMENT OF PALM OIL MILL

\begin{tabular}{|c|c|c|c|c|c|c|c|}
\hline \multirow[b]{2}{*}{ No } & \multirow{2}{*}{$\begin{array}{c}\text { Isolate } \\
\text { Code }\end{array}$} & \multirow{2}{*}{$\begin{array}{c}\text { Gas } \\
\text { Production }\end{array}$} & \multicolumn{2}{|c|}{ Characteristics } & \multicolumn{3}{|c|}{ Ability of Degradation } \\
\hline & & & $\begin{array}{c}\text { Facultative } \\
\text { anaerobe }\end{array}$ & Aerobic & Cellulolytic & Proteolytic & Lipolytic \\
\hline 1 & K.An 1 & $\sqrt{ }$ & $\sqrt{ }$ & & $\sqrt{ }$ & $\sqrt{ }$ & \\
\hline 2 & K.An 2 & $\sqrt{ }$ & $\sqrt{ }$ & & & & \\
\hline 3 & K.An 3 & $\sqrt{ }$ & & $\sqrt{ }$ & & & \\
\hline 4 & K.P 1.1 & $\sqrt{ }$ & & $\sqrt{ }$ & $\sqrt{ }$ & & \\
\hline 5 & K.P 1.2 & $\sqrt{ }$ & $\sqrt{ }$ & & & & $\sqrt{ }$ \\
\hline 6 & K.P 1.3 & $\sqrt{ }$ & & $\sqrt{ }$ & & $\sqrt{ }$ & \\
\hline 7 & K.P 1.4 & $\sqrt{ }$ & $\sqrt{ }$ & & & & \\
\hline 8 & K.P 1.5 & $\sqrt{ }$ & $\sqrt{ }$ & & & $\sqrt{ }$ & \\
\hline 9 & K.P 2.1 & $\sqrt{ }$ & & $\sqrt{ }$ & & & \\
\hline 10 & K.P 2.2 & $\sqrt{ }$ & & $\sqrt{ }$ & & & $\sqrt{ }$ \\
\hline 11 & K.P 2.3 & $\sqrt{ }$ & & $\sqrt{ }$ & & & \\
\hline \multicolumn{8}{|c|}{$\begin{array}{l}\text { Remark: } \\
\sqrt{ } \quad \text { : able or positive test result } \\
\text { K.An: Anaerobic Pond } \\
\text { K.P.1: Cooling Pond } 1 \\
\text { K.P.2: Cooling Pond } 2\end{array}$} \\
\hline
\end{tabular}

Results of selection show two bacteria having potency in anaerobic treatment, that is: K.An 1 and K.P 1.2 code while three bacteria having potency in aerobic treatment, that is: K.P1.1, K.P1.3, and K.P2.2 code as shown in Table 1.

\section{B. Synergism Test Results}

The results of the synergism test are indicated by not forming of inhibition zone around the disc paper that contains the bacterial isolates, otherwise, if the inhibition zone is formed between the bacteria (the bacteria on the agar surface and bacteria on the disc paper are inhibited each other or antagonistic). The complete synergism test results are presented in Table 2. Based on Table 2, the isolates of the synergistic bacteria are KAn-1 \& KP-1-2; Kan-2 \& KP1.2. \& KP-1-1; KP-1.1 \& KP-2-2 \& KP-1-3. These results indicate that three groups of bacteria are mutually synergistic. The first group consists of two bacteria, namely: KAn-1 \& KP-1-2, the second and third groups consist of three bacteria, namely Kan-2 \& KP-1.2. \& KP-1-1 and KP1.1. \& KP-2-2 \& KP-1-3, respectively. 
TABLE II

SYNERGISM TEST RESULTS OF ELEVEN BACTERIAL ISOLATES

\begin{tabular}{|c|c|c|c|c|c|c|c|c|c|c|c|c|}
\hline \multirow[b]{2}{*}{ No } & \multirow{2}{*}{$\begin{array}{c}\text { Code of } \\
\text { isolate at disc } \\
\text { paper }\end{array}$} & \multicolumn{11}{|c|}{ Isolate code at agar surface } \\
\hline & & $\begin{array}{l}\text { K.P } \\
2.3 \\
\end{array}$ & $\begin{array}{l}\text { K.P } \\
2.2 \\
\end{array}$ & $\begin{array}{l}\text { K.P } \\
2.1 \\
\end{array}$ & $\begin{array}{l}\text { K.P } \\
1.5 \\
\end{array}$ & $\begin{array}{l}\text { K.P } \\
1.4 \\
\end{array}$ & $\begin{array}{r}\text { K.P } \\
1.3 \\
\end{array}$ & $\begin{array}{l}\text { K.P } \\
1.2 \\
\end{array}$ & $\begin{array}{r}\text { K.P } \\
1.1 \\
\end{array}$ & $\begin{array}{c}\text { K.An } \\
3 \\
\end{array}$ & $\begin{array}{c}\text { K.An } \\
2 \\
\end{array}$ & $\begin{array}{c}\text { K.An } \\
1\end{array}$ \\
\hline 1 & K.An 1 & - & - & - & - & - & - & + & - & - & - & \\
\hline 2 & K.An 2 & - & - & - & - & - & - & + & + & - & & \\
\hline 3 & K.An 3 & - & - & - & - & - & - & - & - & & & \\
\hline 4 & K.P 1.1 & - & + & - & - & - & + & - & & & & \\
\hline 5 & K.P 1.2 & - & - & - & - & - & - & & & & & \\
\hline 6 & K.P 1.3 & - & + & - & - & - & & & & & & \\
\hline 7 & K.P 1.4 & - & - & - & - & & & & & & & \\
\hline 8 & K.P 1.5 & - & - & - & & & & & & & & \\
\hline 9 & K.P 2.1 & - & - & & & & & & & & & \\
\hline 10 & K.P 2.2 & - & & & & & & & & & & \\
\hline 11 & K.P 2.3 & & & & & & & & & & & \\
\hline
\end{tabular}

Remark: + : sinergism characteristics; - : antagonism characteristics

\section{Identification Results of Bacteria Isolate}

Identification of bacteria results in two groups, which is anaerobic and aerobic bacteria group which has the potency of degrading wastewater component of the palm oil mill. Group of anaerobic bacteria consists of bacterial code KP.1.2 and KAn.1, while that of aerobic bacteria consists of bacterial code KP.1.1, KP.1.3, and KP.2.2. Based on the phylogenetic tree as shown in Figure 2 to Figure 6, each of bacterial isolate identified, that is KAn.1: Bacillus toyonensis strain BCT-7112, KP.1.2: Stenotrophomonas rhizophila strain e-p10, KP1.1: Bacillus cereus ATCC 14579, KP1.3: Pseudomonas azotoformans strain NBRC 12693, and KP2.2: Burkholderia cepacia ATCC 25416.

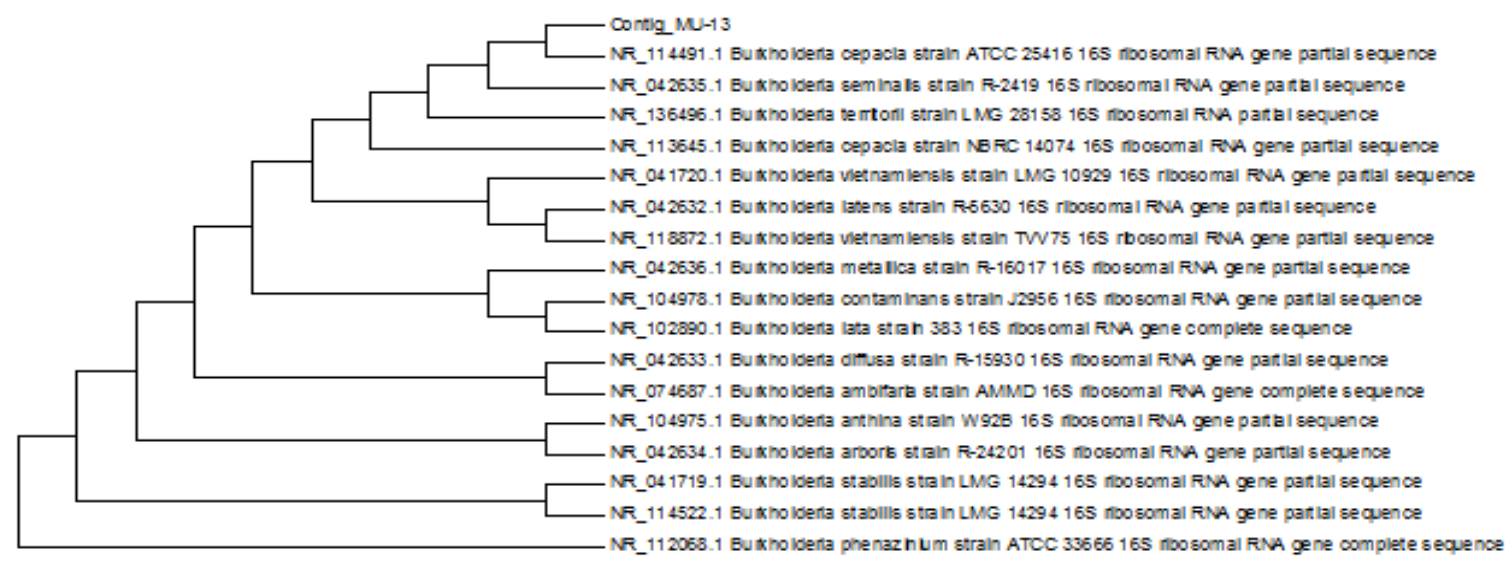

Fig. 2 Phylogenetic tree of the bacterial isolate identification result of KP.2.2 (identification code MU-13)

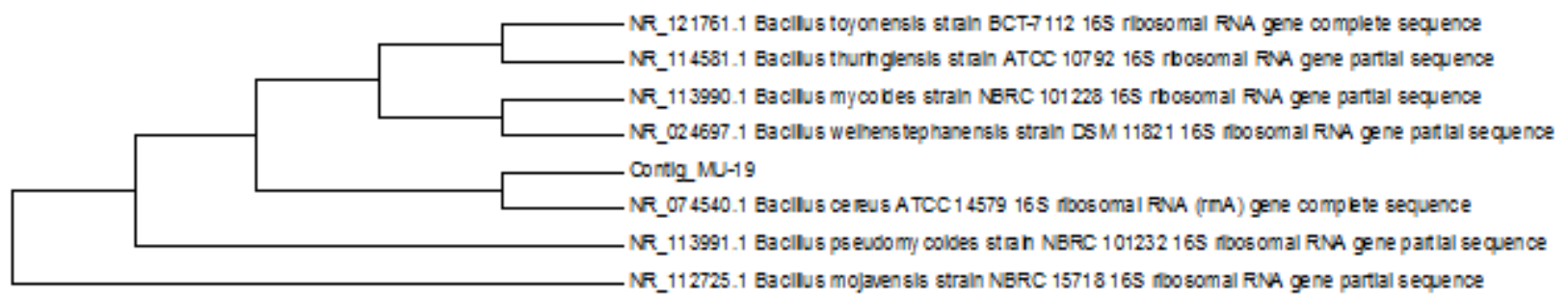

Fig. 3 Phylogenetic tree of the bacterial isolate identification result of KP.1.1 (identification code MU-19) 


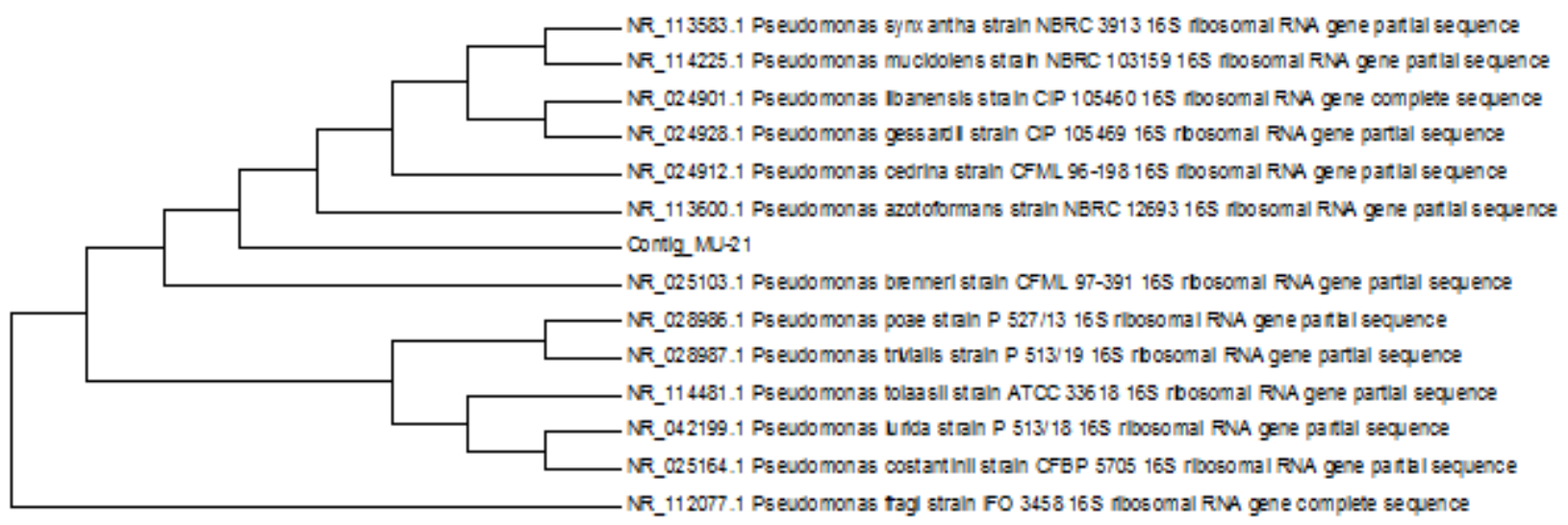

Fig. 4 Phylogenetic tree of the bacterial isolate identification result of KP.1.3 (identification code MU-21)

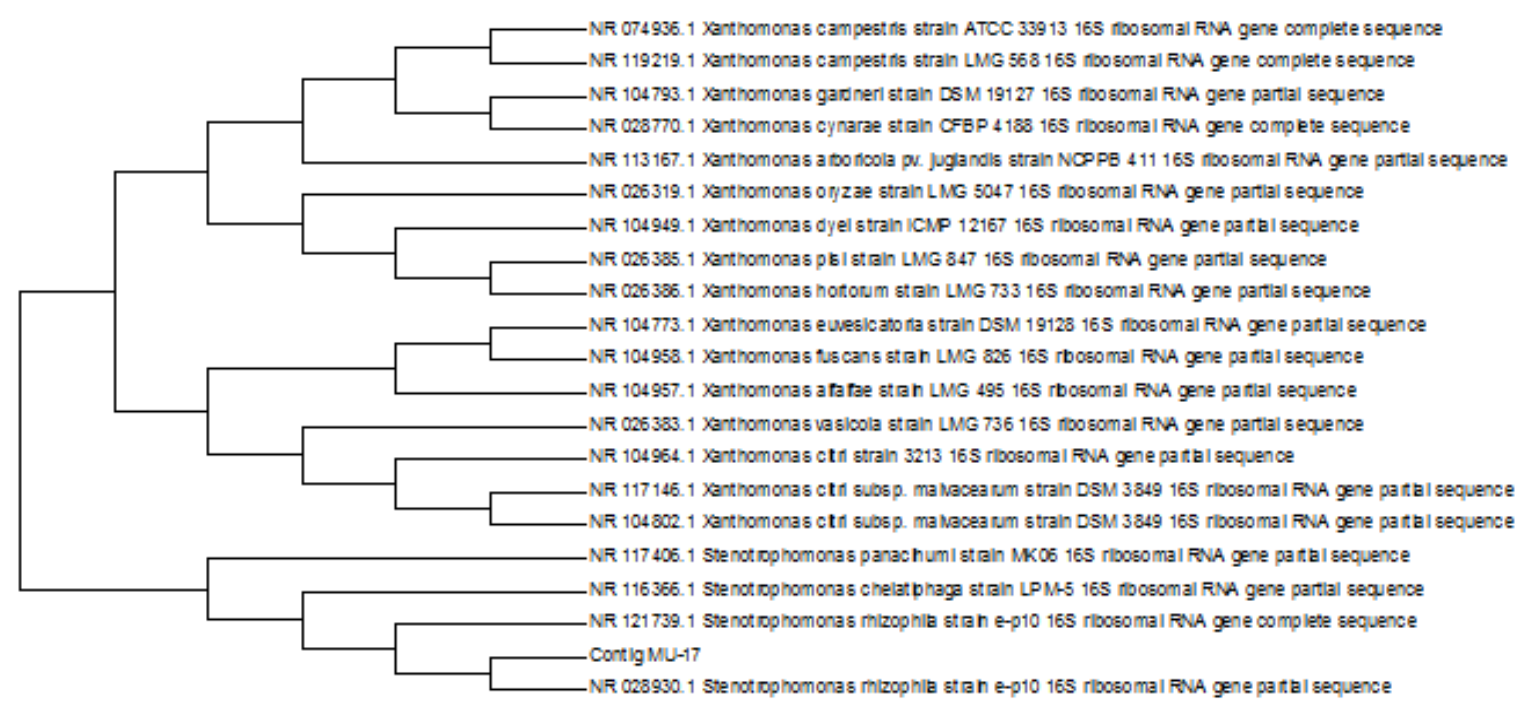

Fig. 5 Phylogenetic tree of the bacterial isolate identification result of KP.1.2 (identification code MU-17)

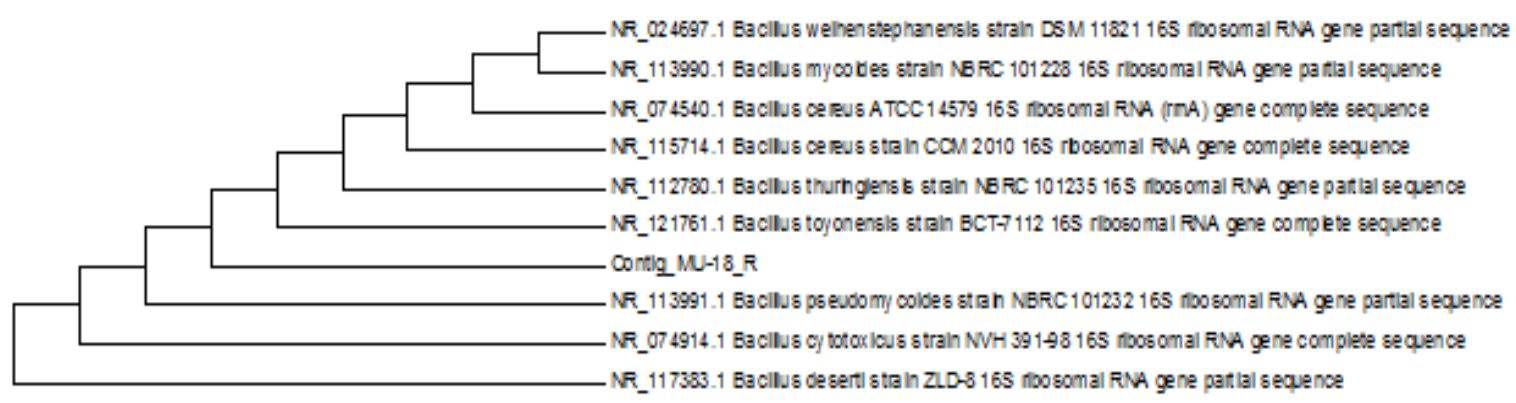

Fig. 6 Phylogenetic tree of the bacterial isolate identification result of KAn.1 (identification code MU-18)

\section{CONCLUSIONS}

Two groups of consortium bacteria have the potency of lipolytic, proteolytic and cellulolytic and each of them has characteristics of aerobic dan facultative anaerobic. The bacteria types in each of the consortium group are synergic. The consortium having facultative anaerobic characteristics consists of Bacillus toyonensis strain BCT-7112 with cellulolytic-lipolytic characteristics and Stenotrophomonas rhizophila strain e-p10 with proteolytic characteristics, while the consortium of aerobic consists of Bacillus cereus ATCC 14579 with cellulolytic characteristics, Pseudomonas azotoformans strain NBRC 12693 with proteolytic characteristics and Burkholderia cepacia ATCC 25416 with lipolytic characteristics. 


\section{ACKNOWLEDGMENT}

The authors thank LPPM Sriwijaya University for the support of finance to conduct the research and to Biology Department Faculty of Mathematics and Natural Science Sriwijaya University for the support of laboratory facilities during the study.

\section{REFERENCES}

[1] L. Ali, N. Hasnain, W. Amna, Gul-e-Sahra and A. Tauseef, Screening of oil-contaminated soil for isolation of lipids degrading bacteria, Sci.Int. 26(4) (2014) 1595-1600.

[2] J.L. Arpigny and J. Karl-Erich, Bacterial lipolytic enzymes: classification and characteristics. Biochem. J. 343(1999)177-183,

[3] N.C. Bestari and Suharjono, Activity Assay and Identification of Lipolytic Bacteria from Wastewater Fish Industry at District Muncar, Banyuwangi Indonesia, Int.J. ChemTech Res. 8(11)(2015)377-383.

[4] A.L Giudice, L. Michaud, D. de Pascale, M. De Domenico, G. di Prisco, R. Fani, and V. Bruni1, Lipolytic activity of Antarctic coldadapted marine bacteria (Terra Nova Bay, Ross Sea), Journal of Applied Microbiology 101(2006)1039-1048.

[5] L.P. Lee, M.K. Hudzaifah, C. Marimuthu, Subash C. B. Gopinath, L. Thangavel and T. Thean-Hock, Lipase-Secreting Bacillus Species in an Oil-Contaminated Habitat: Promising Strains to Alleviate Oil Pollution, BioMed Research International (2015)1-9.

[6] C.K. Lodha, S. Kumar and R. S. Awasthi, Screening of Lipolytic Fungi from Oily Premises for Biosurfactant Production, World Journal of Pharmacy and Pharmaceutical Sciences 5(5)(2016)11761181

[7] B. Mandepudi, V.C. Ghanta and D. Mandepudi, Fermentation of vegetable oils in the light of lipolytic activity with lipase producing bacterial isolates from soil samples, International Journal of Pharmaceutical Applications 3(2) (2012)352-359.

[8] A.T. Odeyemi, B.I. Aderiye and O.S. Bamidele, Lipolytic activity of some strains of Klebsiella, pseudomonas and Staphylococcus spp. from restaurant wastewater and receiving the stream, Journal of Microbiology Research 3(1)(2013)43-52.
[9] P.Pallavi, T. Ravikumar and S. Ram Reddy, Isolation and characterization of lipase-producing bacteria for biodegradation of oil contamination, Int. J. Curr. Res. Aca., Rev 3(8)(2015) 56-66.

[10] N.T. Phong, N.T. Duyen, C.N. Diep, Isolation and characterization of lipid-degrading bacteria in wastewater of food processing plants and restaurants in Can Tho city, Vietnam, American Journal of Life Sciences 2(6)(2014)382-388.

[11] O.N. Donkor, A. Henriksson, T. Vasiljevic, N. P. Shah, Proteolytic activity of dairy lactic acid bacteria and probiotics as a determinant of growth Ana in vitro angiotensin-converting enzyme inhibitory activity in fermented milk, Le Lait 87(1)(2007)21-38.

[12] M.P. Rodarte, D. R. Dias, D.M. Vilela and R.F. Schwan, Proteolytic activities of bacteria, yeasts and filamentous fungi isolated from coffee fruit (Coffea arabica L.) Maringá, 33(3) (2011)457-464.

[13] S.V. Megha and B. Annadurai. Isolation and Identification of Proteolytic Bacteria from Raw Milk Samples, G.J.B.B, 3(4) (2014) 391-397.

[14] D. Rupali, Screening and Isolation of Protease Producing Bacteria from Soil Collected from Different Areas of Burhanpur Region (MP) India, Int.J.Curr.Microbiol.App.Sci. 4(8) (2015)597-606.

[15] A. Balamurugan, R. Jayanthi, P. Nepolean, R.V. Pallavi and R. Premkumar, Studies on cellulose degrading bacteria in tea garden soils, African Journal of Plant Science 5(1) (2011)22-27.

[16] S.K. Dubey, R. K. Meena, S. Sao, J. Patel, S. Thakur and P. Shukla, Isolation and haracterization of Cellulose Degrading Bacteria from Biogas Slurry and their RAPD profiling, Curr Res Microbiol Biotechnol. 2(4) (2014)416-421.

[17] S. Hatami, H.A. Alikhani, H. Besharati, N. Salehrastin, M. Afrousheh and Z.Y. Jahromi, Investigation on Aerobic Cellulolytic Bacteria in Some of North Forest and Farming Soils, AmericanEurasian J. Agric. \& Environ. Sci. 3(5) (2008)713-716.

[18] S. Huang, P. Sheng and H. Zhang, Isolation and Identification of Cellulolytic Bacteria from the Gut of Holotrichia parallela Larvae (Coleoptera: Scarabaeidae), Int. J. Mol. Sci. 13(2013)2563-2577.

[19] M. Irfan, A. Safdar, Q. Syed and M. Nadee, Isolation and screening of cellulolytic bacteria from soil and optimization of cellulase production and activity, Turk J Biochem. 37(3) (2012)287-293.

[20] M. Wenzel, I. SchoË nig, M. Berchtold, P. KaÈmpfer and H. KoÈ nig, Aerobic and facultatively anaerobic cellulolytic bacteria from the gut of the termite Zootermopsis angusticollis, Journal of Applied Microbiology. 92(2002)32-40. 